\title{
Soot Oxidation in Diesel Exhaust on Silver Catalyst Supported by Alumina, Titanium and Zirconium
}

\author{
Punya Promhuad ${ }^{1,2, *}$ and Boonlue Sawatmongkhon ${ }^{1,2}$ \\ ${ }^{1}$ College of Industrial Technology, King Mongkut's University of Technology North Bangkok, 1518 Pracharat 1 Road, Wongsawang, \\ Bangsue, Bangkok 10800, Thailand.
}

${ }^{2}$ Research Centre for Combustion Technology and Alternative Energy (CTAE), Science and Technology Research Institute, King Mongkut's University of Technology North Bangkok, Thailand.

\begin{abstract}
Diesel Particulate Filter (DPF) is used to limit the emission of particulate matter (PM). The operation of DPF has two consecutive functions which are filtration of PM and regeneration. Performance of DPF is reduced by clogging of the filter. This problem is improved by soot oxidation in the regeneration process. The soot is completely oxidized by oxygen when temperature is higher than $600{ }^{\circ} \mathrm{C}$. However, the exhaust gas temperature in normal operating of the diesel engine is lower than the temperature of soot complete oxidation. The problem of low temperature in soot oxidation is improved by oxidation catalyst because the oxidation catalyst is used to reduce light of temperature in soot oxidation. The study's purpose is to compare the oxidation activity of silver catalyst supported on alumina $\left(\mathrm{Al}_{2} \mathrm{O}_{3}\right)$, Titanium oxide $\left(\mathrm{TiO}_{2}\right)$, and Zirconium oxide $\left(\mathrm{ZrO}_{2}\right)$. The compression of soot oxidation on silver catalyst loaded on several support which showed silver base on alumina was the best of soot oxidation compared with titanium oxide and zirconium oxide. The behaviour of soot oxidation in silver base on titanium oxide and zirconium oxide were similar activity.
\end{abstract}

Keyword. Soot oxidation, Silver catalyst, $\mathrm{TiO}_{2}, \mathrm{ZrO}_{2}$

\section{Introduction}

Air pollution from the emissions of diesel vehicles, such as particulate matter (PM) and nitrogen oxides (NOx), has been caused harm to human health [1]. There are many technologies to reduce the pollution such as using the biodiesel as fuel in diesel engine, and installation of exhaust gas after-treatment system. The diesel engine used biodiesel as fuel that it showed low emission such as hydrocarbon, carbon monoxide, smoke[2].Currently, diesel particulate filter (DPF) is the device used to control effectively PM emissions[1, 3-4]. The operating of DPF consists of two sequential processes, which are trapping of soot and regeneration. First, the trapping of soot is the process of soot to deposit in porous walls of DPF [3]. Next, the regeneration of DPF is required to reduce the problem of DPF blockages. In normal, soot is oxidized by oxygen at a temperature higher than $600^{\circ} \mathrm{C}$ [5-7], which is over the exhaust gas temperature in diesel engine.

The oxidation of soot was promoted using an oxidation catalyst, which assisted to burn soot at lower then temperatures of exhaust gas in diesel engine. Noble-metal (such as $\mathrm{Ag}, \mathrm{Au}, \mathrm{Pd}, \mathrm{Ru}$, and Pt etc.) were used as the active metal in oxidation catalyst [8-9]. Silver was interested as the oxidation catalyst because it prompted active oxygen species [10-12] and showed high stability [3]. Moreover, silver is cheaper than other noble metals (e.g., Pt) [13]. The oxygen species or active oxygen may be classified in to peroxide $\left(\mathrm{O}^{-}\right)$and superoxide $\left(\mathrm{O}^{2-}\right)$. The active oxygen transfer to soot which was considered to be an important for soot oxidation activity $[4,14]$.

Soot oxidation activity was promoted by not only the active metal but also the support materials, such as, $\mathrm{Al}_{2} \mathrm{O}_{3} \mathrm{TiO}_{2}, \mathrm{ZrO}_{2}$, and $\mathrm{CeO}_{2}$. Alumina was widely used as the support material of oxidation catalysts, such as, $\mathrm{Pt} / \mathrm{Al}_{2} \mathrm{O}_{3}$ [15] and $\mathrm{Ag} / \mathrm{Al}_{2} \mathrm{O}_{3}[3,12]$. Silver catalyst 16 $w t \%$ coated on alumina showed best soot oxidation [3]. The $\mathrm{Ag} / \mathrm{ZrO}_{2}$ showed a promising candidate for oxidizing soot with $\mathrm{O}_{2}$ when the mole fraction of adding $\mathrm{Ag}$ to $\mathrm{ZrO}_{2}$ was $30 \%$ in citric acid-assisted sol-gel (SG) methods [11]. Moreover, it showed very active catalysts in a fresh or aged state [12]. The titanium oxide, which used with silver catalyst, showed high oxidation efficiency of soot in the tight contact between catalyst and soot [16]. From, several works of literature caused interest in the oxide materials to use with silver metal such as $\mathrm{Al}_{2} \mathrm{O}_{3}, \mathrm{TiO}_{2}$, and $\mathrm{ZrO}_{2}$.

The thermogravimetric (TG) methods was used to determine kinetics parameter such as activation energy (Ea) and frequency factor $(f(\alpha))$ etc. Normally, the activation energy is important kinetic parameter to explain the reaction process and identify the reaction mechanism [17]. The reaction rate of a heterogeneous reaction The Arrhenius equation, which depends on temperature, was used to describe the rate of soot oxidation [18]. The rate of reaction in the case of constant heating rate can be explained by the following equation [19] :

Corresponding author: s6303026912014@kmutnb.ac.th 


$$
\frac{d \alpha}{d T}=\frac{A}{\beta} \exp \left(\frac{-E a}{R T}\right) f(\alpha)
$$

when $\mathrm{A}$ and Ea are the frequency factor and activation energy, $f(\alpha)$ is the differential conversion function, $\beta$ is heating rate and $\mathrm{R}$ is the universal gas constant. The mass faction of the soot oxidation decomposition $(\alpha)$ can be calculated by the following equation:

$$
\alpha=\frac{m-m_{0}}{m-m_{\mathrm{f}}}
$$

when $\mathrm{m}$ is the instantaneous mass of soot, $\mathrm{m}_{0}$ is the initial mass, and $\mathrm{m}_{\mathrm{f}}$ is the final mass. In this work used the Kissinger-Akahira-Sunose to determine activation energy to the following equation[20] :

$$
\ln \left(\frac{\beta}{T^{1.92}}\right)=\text { Const }-1.0008\left(\frac{E a}{R T}\right)
$$

The activation energy can be obtained by slope from plot of $\ln \left(\beta / \mathrm{T}^{1.92}\right)$ against $1 / \mathrm{T}$ for different heating rates at a constant $\alpha$ [20]. From equation (3) can be calculated the activation energy by equation as the following:

$$
E a=\frac{(\text { slope at } \alpha) \times R}{-1.0008}
$$

The aim of the following study was to compare the soot oxidation activity of silver catalyst loaded on three metal-oxide supports (e.g., $\mathrm{Al}_{2} \mathrm{O}_{3}, \mathrm{TiO}_{2}$, and $\mathrm{ZrO}_{2}$ ) and find the activation energy from soot oxidation. The activity of soot oxidation was used by thermogravimetric (TG) methods in the three heating rates which were 5, 7.5 , and $10^{\circ} \mathrm{C} / \mathrm{min}$. The activation energy was calculated by KAS method.

\section{Experimental}

\subsection{Catalyst and soot preparation}

The silver catalyst used on different supporters was prepared via incipient wetness impregnation that silver nitrate to obtain $16 \mathrm{wt} \%$ was dissolved in an appropriate quantity of distilled water [3]. Then, the precursor solution was added dropwise to the powdered supports: $\gamma$-alumina, titanium oxide, and zirconium oxide. Then, the solvent was removed by drying at $110^{\circ} \mathrm{C}$ for $8 \mathrm{~h}$ in an oven. Then, the dry sample will be calcined in static air at $600{ }^{\circ} \mathrm{C}$ with a heating rate of $10^{\circ} \mathrm{C} / \mathrm{min}$ for $2 \mathrm{~h}$.

Soot was directly taken from the exhaust gas of a traditional diesel engine. The engine was operated at a speed of $1000-2000 \mathrm{rpm}$ and load of $25-75 \%$ of the maximum load. A stain less steel mesh was rolled at one round and placed inside the exhaust pipe (50 mm ID) then, the trapped soot was collected and dried in a furnace at $110^{\circ} \mathrm{C}$ for $8 \mathrm{~h}$ [3]. SOF was removed in furnace at $250^{\circ} \mathrm{C}$ for $2 \mathrm{~h}$.

\subsection{Catalyst activity tests}

Catalytic oxidation activity of soot was examined using the TGA method (PerkinElmer® Pyris 1$)$. Soot $(10 \mathrm{mg})$ was physically mixed with the catalyst at the designed weight ratio for $5 \mathrm{~min}$ in a stainless steel mortar to obtain the tight contact mode or was shaken for $5 \mathrm{~min}$ in a glass tube for the loose contact conditions. Then, the mixture $(\approx 10 \mathrm{mg})$ was sampled and placed in a ceramic crucible and heated from room temperature to $110{ }^{\circ} \mathrm{C}$ with a heating rate of $10{ }^{\circ} \mathrm{C} / \mathrm{min}$ under $\mathrm{N}_{2}$ and, then, the purge gas was switched to $\mathrm{O}_{2}$ until temperature 700 with heating rates of $5{ }^{\circ} \mathrm{C} / \mathrm{min}, 7.5^{\circ} \mathrm{C} / \mathrm{min}$, and $10{ }^{\circ} \mathrm{C} / \mathrm{min}$ and the contact of soot on the catalyst is tight contact. Purified oxygen $(99.999 \%$ purity) with a constant flow rate of $50 \mathrm{~cm}^{3} / \mathrm{min}$ was used as the oxidiser. The sample weight was recorded continuously with the change in the temperature. The catalytic activity was assessed by using the following: $T_{20}$, defined as the onset temperature at which $20 \%$ of soot was removed; $\mathrm{T}_{50}$, defined as the temperature at which of soot $50 \%$ was completely consumed; $\mathrm{T}_{90}$, defined as the temperature at which $90 \%$ of soot oxidation.

\section{Result and Discussion}

\subsection{Diesel soot oxidation}

The thermogram profile and its first derivative (DTG) for soot oxidation under the tight contact mode are presented in Fig. 1-3. The $\mathrm{x}$-axis shows the temperature, the $y$-axis shows the percentage of soot oxidation in figure (a), and the y-axis shows the first derivative of soot oxidation in figure (b). An oxidation reaction was the only interaction of soot (solid carbon) because the SOF was removed in the soot preparation stage. The DTG showed the maximum reaction rate in the oxidation process [3]. In case of pure soot in all the heating rates showed the peak of DTG at $610{ }^{\circ} \mathrm{C}$. It explained the best of oxidation reaction of pure soot at this temperature which confirmed the soot is oxidized by oxygen at a temperature higher than $600{ }^{\circ} \mathrm{C}[5-7]$.

In the case of soot used in conjunction with silver supported by alumina. The oxidation of soot was well promoted by $\mathrm{Ag} / \mathrm{Al}_{2} \mathrm{O}_{3}$ as observed from the experimental results from all heating rates. The heating rate was $5{ }^{\circ} \mathrm{C} / \mathrm{min}$. The peak of DTG showed the maximum oxidation rate temperature was reduced from $610{ }^{\circ} \mathrm{C}$, in the case of non-catalyst soot, to $353{ }^{\circ} \mathrm{C}$ (shows in Fig.1) In case of the heating rate was 7.5 ${ }^{\circ} \mathrm{C} / \mathrm{min}$ and $10{ }^{\circ} \mathrm{C} / \mathrm{min}$. The result showed similarly the oxidation of soot with case of $5{ }^{\circ} \mathrm{C} / \mathrm{min}$. In the case of the heating rate was $7.5{ }^{\circ} \mathrm{C} / \mathrm{min}$ and $10{ }^{\circ} \mathrm{C} / \mathrm{min}$. The result showed similarly the oxidation of soot with a case of $5{ }^{\circ} \mathrm{C} / \mathrm{min}$ from the peak of DTG at $359^{\circ} \mathrm{C}$ and $405^{\circ} \mathrm{C}$ in cases $7.5^{\circ} \mathrm{C} / \mathrm{min}$ and $10^{\circ} \mathrm{C} / \mathrm{min}$, respectively (shows in Fig. 2-3). 

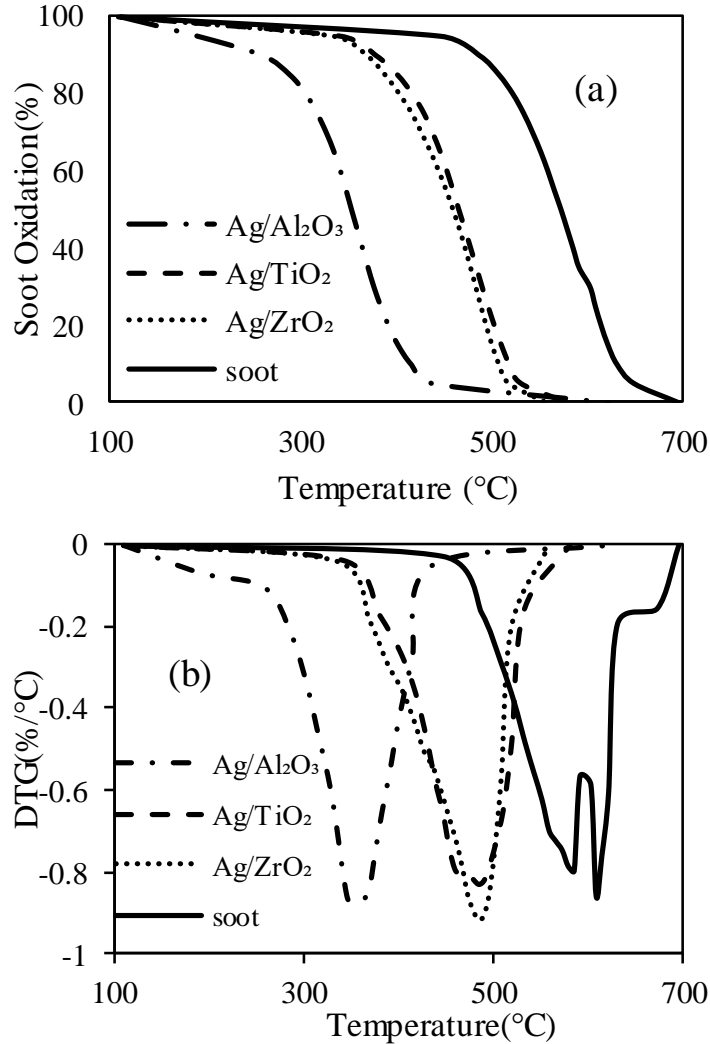

Fig. 1. (a) Thermogravimetric and (b) first derivative profiles of soot oxidation; soot/catalyst weight ratio of $1 / 5$ and heating rate of $5^{\circ} \mathrm{C} / \mathrm{min}$.

The cases of $\mathrm{Ag} / \mathrm{TiO}_{2}$ and $\mathrm{Ag} / \mathrm{ZrO}_{2}$ showed a similar promotion in soot oxidation due to similar soot oxidation temperatures. $\mathrm{Ag} / \mathrm{ZrO}_{2}$ showed the peak of DTG at temperatures values were $485{ }^{\circ} \mathrm{C}, 508{ }^{\circ} \mathrm{C}$, and $541{ }^{\circ} \mathrm{C}$ for heating rates of $5,7.5$, and 10 , respectively (shows in Fig.1-3). $\mathrm{Ag} / \mathrm{TiO}_{2}$ showed the peak of DTG at temperature values were $485^{\circ} \mathrm{C}, 528^{\circ} \mathrm{C}$, and $528^{\circ} \mathrm{C}$ for heating rates of $5{ }^{\circ} \mathrm{C} / \mathrm{min}, 7.5^{\circ} \mathrm{C} / \mathrm{min}$, and $10^{\circ} \mathrm{C} / \mathrm{min}$, respectively (shows in Fig. 1-3). However, the comparison of $\mathrm{Ag} / \mathrm{TiO}_{2}$ and $\mathrm{Ag} / \mathrm{ZrO}_{2}$ showed that $\mathrm{Ag} / \mathrm{ZrO}_{2}$ had a better-promoting effect on oxidation because the temperature at peak of DTG in the case of $\mathrm{Ag} / \mathrm{ZrO} \mathrm{O}_{2}$ represented a lower temperature than the case $\mathrm{Ag} / \mathrm{TiO}_{2}$.

Fig.4-6 show $\mathrm{T}_{20}, \mathrm{~T}_{50}$ and $\mathrm{T}_{90}$ from the experiment had three heating rates which were $5{ }^{\circ} \mathrm{C} / \mathrm{min}, 7.5$ ${ }^{\circ} \mathrm{C} / \mathrm{min}$, and $10^{\circ} \mathrm{C} / \mathrm{min}$. According to Fig.4-6 explained the temperature of percenter of soot decomposition since it was oxidized by oxygen. The $\mathrm{T}_{20}$ explained the $20 \%$ of soot oxidation. $\mathrm{T}_{20}$ may be indicated as a light of temperature which was the start of soot oxidation. In case of $\mathrm{Ag} / \mathrm{Al}_{2} \mathrm{O}_{3}$ presented excellent to reduce the light of temperature for soot oxidation from $523{ }^{\circ} \mathrm{C}$ in case of pure soot was reduced to $305{ }^{\circ} \mathrm{C}$ with heating rate 5 ${ }^{\circ} \mathrm{C} / \mathrm{min}$. The results at heating rate $7.5^{\circ} \mathrm{C} / \mathrm{min}$ and 10 ${ }^{\circ} \mathrm{C} / \mathrm{min}$ showed to similar in case of $5{ }^{\circ} \mathrm{C} / \mathrm{min}$, they were $\mathrm{T}_{20}=310^{\circ} \mathrm{C}$ and $\mathrm{T}_{20}=342{ }^{\circ} \mathrm{C}$ with heating rates of $7.5^{\circ} \mathrm{C}$, and $10^{\circ} \mathrm{C}$, respectively. In case of $\mathrm{Ag} / \mathrm{TiO}_{2}$ presented $\mathrm{T}_{20}$ were $417^{\circ} \mathrm{C}, 438^{\circ} \mathrm{C}$, and $452{ }^{\circ} \mathrm{C}$ with heating rates of
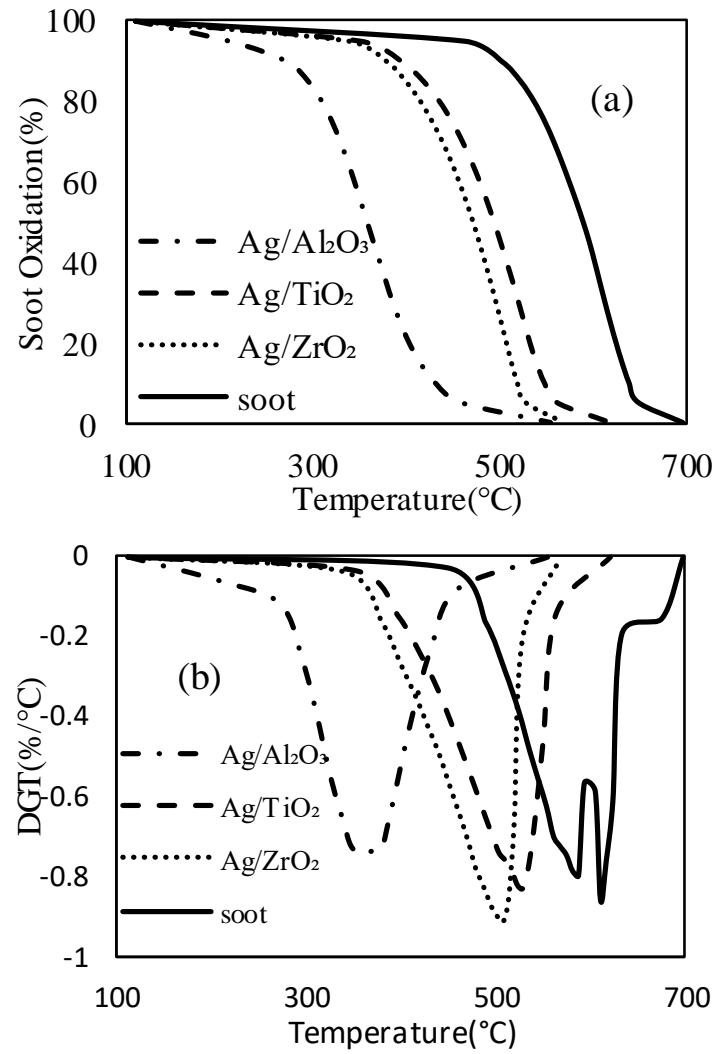

Fig. 2. (a) Thermogravimetric and (b) first derivative profiles of soot oxidation; soot/catalyst weight ratio of $1 / 5$ and heating rate of $7.5^{\circ} \mathrm{C} / \mathrm{min}$.

$5^{\circ} \mathrm{C} / \mathrm{min}, 7.5^{\circ} \mathrm{C} / \mathrm{min}$, and $10{ }^{\circ} \mathrm{C} / \mathrm{min}$, respectively. The result from $\mathrm{Ag} / \mathrm{ZrO}_{2}$ showed $\mathrm{T}_{20}$ were $404{ }^{\circ} \mathrm{C}, 416{ }^{\circ} \mathrm{C}$, and $437{ }^{\circ} \mathrm{C}$ with heating rates of $5{ }^{\circ} \mathrm{C} / \mathrm{min}, 7.5^{\circ} \mathrm{C} / \mathrm{min}$, and 10 ${ }^{\circ} \mathrm{C} / \mathrm{min}$, respectively. The result in several cases in the experiment presented shows light of temperature for soot oxidation as follows: $\mathrm{Ag} / \mathrm{Al}_{2} \mathrm{O}_{3}<\mathrm{Ag} / \mathrm{ZrO}_{2}<\mathrm{Ag} / \mathrm{TiO}_{2}<$ pure soot. It showed the effect of metal oxides supporter to promote soot oxidation because light of temperature for soot oxidation was reduced from pure soot oxidation. In the case of soot oxidation from $\mathrm{Ag} / \mathrm{TiO}_{2}$ and $\mathrm{Ag} / \mathrm{ZrO}$. The $\mathrm{T}_{20}$ were similar values, it explained the light of soot oxidation which show similar activity in all the heating rates.

The soot oxidation performance was explained by $\mathrm{T}_{50}$ and $\mathrm{T}_{90}$. They were temperature at soot decomposition at $50 \%\left(\mathrm{~T}_{50}\right)$ and $90 \%\left(\mathrm{~T}_{90}\right)$ from initial mass. The results of $\mathrm{T}_{50}$ in case of $\mathrm{Ag} / \mathrm{Al}_{2} \mathrm{O}_{3}$ was shown in Fig.4-6. The $\mathrm{T}_{50}$ were $353{ }^{\circ} \mathrm{C}$ with a heating rate of 5 ${ }^{\circ} \mathrm{C} / \mathrm{min}$. In the case of heating rates were $7^{\circ} \mathrm{C} / \mathrm{min}$ and $10^{\circ} \mathrm{C} / \mathrm{min}$ that they showed $\mathrm{T}_{50}=359{ }^{\circ} \mathrm{C}$ and $\mathrm{T}_{90}=398$ ${ }^{\circ} \mathrm{C}$, respectively. The $\mathrm{T}_{90}$ were $353{ }^{\circ} \mathrm{C}$ with a heating rate of $5{ }^{\circ} \mathrm{C} / \mathrm{min}, 359^{\circ} \mathrm{C}$ with $7{ }^{\circ} \mathrm{C} / \mathrm{min}$ and $398^{\circ} \mathrm{C}$ with 10 ${ }^{\circ} \mathrm{C} / \mathrm{min}$. The results of a silver catalyst supported by alumina showed a good assister to promote soot oxidation. As it reduced the $\mathrm{T}_{50}$ and $\mathrm{T}_{90}$ by half from the case of pure soot. The $T_{50}$ and $T_{90}$ in the case of a silver catalyst supported by titanium oxide is shown in Fig.4 Fig.6. 

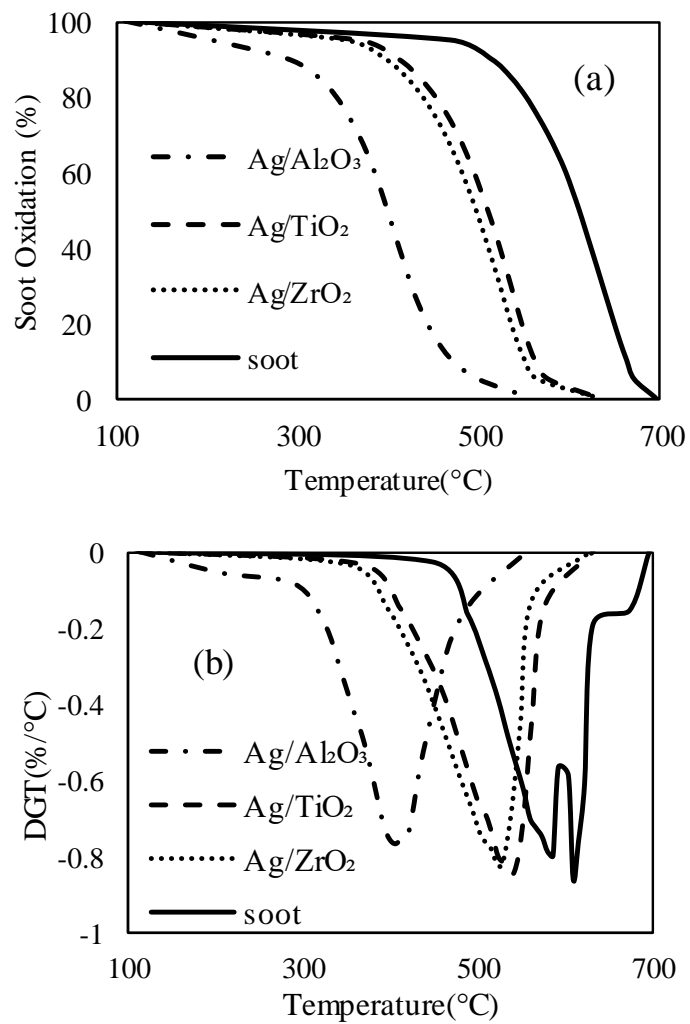

Fig. 3. (a) Thermogravimetric and (b) first derivative profiles of soot oxidation; soot/catalyst weight ratio of $1 / 5$ and heating rate of $10^{\circ} \mathrm{C} / \mathrm{min}$.

In these cases, the $\mathrm{T}_{50}$ were $466{ }^{\circ} \mathrm{C}, 495{ }^{\circ} \mathrm{C}$, and $509{ }^{\circ} \mathrm{C}$ with heating rates of $5{ }^{\circ} \mathrm{C} / \mathrm{min}, 7.5^{\circ} \mathrm{C} / \mathrm{min}$, and 10 ${ }^{\circ} \mathrm{C} /$ min, respectively. $\mathrm{T}_{90}$ were $519{ }^{\circ} \mathrm{C}, 549{ }^{\circ} \mathrm{C}$, and $562{ }^{\circ} \mathrm{C}$ with heating rates of $5{ }^{\circ} \mathrm{C} / \mathrm{min}, 7.5^{\circ} \mathrm{C} / \mathrm{min}$, and 10 ${ }^{\circ} \mathrm{C} / \mathrm{min}$, respectively. In case of silver catalyst supported by zirconium oxide presented T50 $=461{ }^{\circ} \mathrm{C}$ with heating rate $5{ }^{\circ} \mathrm{C} / \mathrm{min}, \mathrm{T}_{50}=473{ }^{\circ} \mathrm{C}$ with heating rate $7.5^{\circ} \mathrm{C} / \mathrm{min}$, and $\mathrm{T}_{50}=495{ }^{\circ} \mathrm{C}$ with heating rate $10{ }^{\circ} \mathrm{C} / \mathrm{min}$. The T90 from $\mathrm{Ag} / \mathrm{ZrO}_{2}$ were $519{ }^{\circ} \mathrm{C}, 549{ }^{\circ} \mathrm{C}$, and $562{ }^{\circ} \mathrm{C}$ with heating rates of $5{ }^{\circ} \mathrm{C} / \mathrm{min}, 7.5^{\circ} \mathrm{C} / \mathrm{min}$, and $10{ }^{\circ} \mathrm{C} / \mathrm{min}$, respectively. The results of $\mathrm{T} 50$ and $\mathrm{T} 90$ from $\mathrm{Ag} / \mathrm{TiO}_{2}$ and $\mathrm{Ag} / \mathrm{ZrO} \mathrm{r}_{2}$ showed a similar performance to promote soot oxidation. Because $\mathrm{T} 50$ and $\mathrm{T}_{90}$ in the case of $\mathrm{Ag} / \mathrm{ZrO}_{2}$ and $\mathrm{Ag} / \mathrm{TiO}_{2}$ were slightly different temperatures. It confirmed the similar activity in soot oxidation. The comparison of soot oxidation performance in several case showed as follows: Ag $/ \mathrm{Al}_{2} \mathrm{O}_{3}<\mathrm{Ag} / \mathrm{ZrO}_{2}<\mathrm{Ag} / \mathrm{TiO}_{2}<$ pure soot. From the results of silver catalyst supported by alumina showed high performance for soot oxidation from the result. Because of it presented to low $\mathrm{T} 50$ and $\mathrm{T}_{90}$ which compared with $\mathrm{Ag} / \mathrm{TiO}_{2}, \mathrm{Ag} / \mathrm{ZrO}_{2}$, and pure soot in all heating rates.

\subsection{Activation energy}

The results of the analysis for the determination of Ea used KAS method, it is necessary to find the slope of the plot of $\ln \left(\beta / \mathrm{T}^{1.92}\right)$ against $1 / \mathrm{T}$ for different heating rates at a constant $\alpha=0.1$ to $\alpha=0.9$ which showed soot decomposition.

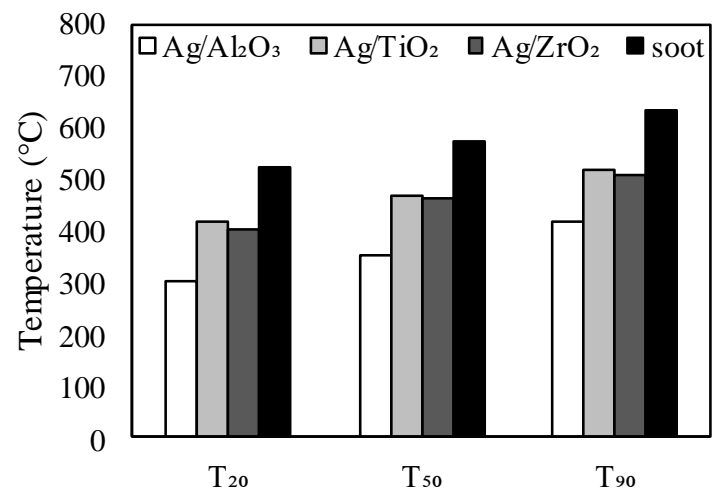

Fig. 4. $T_{20}, T_{50}$, and $T_{90}$ of soot oxidation (heating rate $5^{\circ} \mathrm{C} / \mathrm{min}$ )

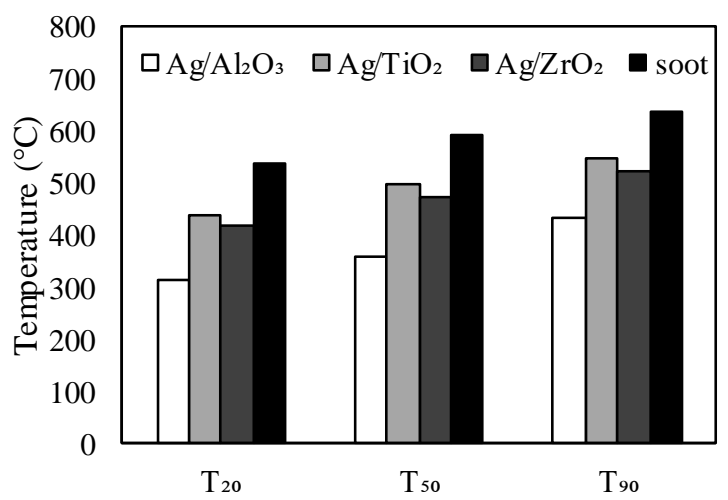

Fig. 5. $\mathrm{T}_{20}, \mathrm{~T}_{50}$, and $\mathrm{T}_{90}$ of soot oxidation (heating rate $7.5^{\circ} \mathrm{C} / \mathrm{min}$ )

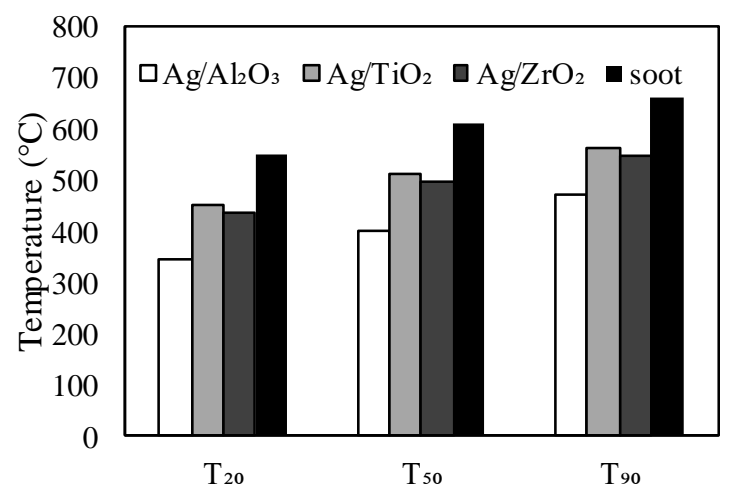

Fig. 6. $\mathrm{T}_{20}, \mathrm{~T}_{50}$, and $\mathrm{T}_{90}$ of soot oxidation (heating rate $\left.10^{\circ} \mathrm{C} / \mathrm{min}\right)$

The case of soot oxidation on the catalyst base on alumina supporter was presented in Fig. 7. it showed $\alpha$ for determine slope of the plot of $\ln (\beta / \mathrm{T} 1.92)$ against $1 / \mathrm{T}$. From result of calculation in this condition made to activation energy were between 33-49 kJ/mol.Fig.8 and Fig. 9 show the plot of $\ln \left(\beta / \mathrm{T}^{1.92}\right)$ against $1 / \mathrm{T}$ and in case of silver catalyst base on titanium oxide can be calculate the activation energy were between $64-79 \mathrm{~kJ} / \mathrm{mol}$ and case of silver catalyst base on zirconium oxide can be calculate the activation energy were between 71-81 $\mathrm{kJ} / \mathrm{mol}$. In case pure soot, the plot of $\ln \left(\beta / \mathrm{T}^{1.92}\right)$ against $1 / \mathrm{T}$ is shown in Fig.10, can be fined the activation energy were between $103-128 \mathrm{~kJ} / \mathrm{mol}$. Fig. 11 presents the comparison of the activation energy from soot 
oxidation in four condition. From results of activation energy were one to explain the performance of soot oxidation. The several cases of silver catalyst base on different metal oxides support showed different activation energy too. This result showed highest of activation energy in pure soot. However. soot loaded on silver catalyst supported by oxide metal. It showed to reduce the activation energy. In the best case of soot oxidation was a silver catalyst supported by alumina because the result of maximum rate oxidation reaction, $\mathrm{T}_{20}, \mathrm{~T}_{50}, \mathrm{~T}_{90}$, and activation energy which the most reduced form pure soot oxidation. It attributed alumina well to promote soot oxidation activity. In case of silver catalyst base on titanium oxide and zirconium oxide showed similar of the result to reduce the activation energy, T20, T50, and T90 from the oxidation of pure soot.

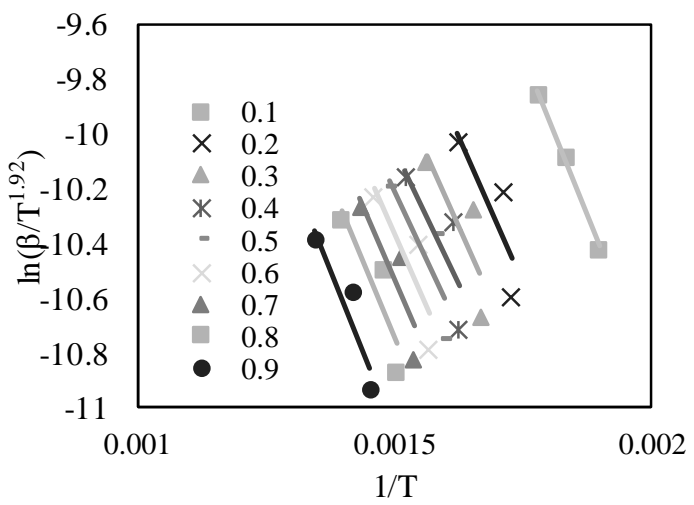

Fig. 7. The plot of $\ln \left(\beta / \mathrm{T}^{1.92}\right)$ against $1 / \mathrm{T}$ for different heating rates at a constant $\alpha=0.1$ to $\alpha=0.9$ in $\mathrm{Ag} / \mathrm{Al}_{2} \mathrm{O}_{3}$.

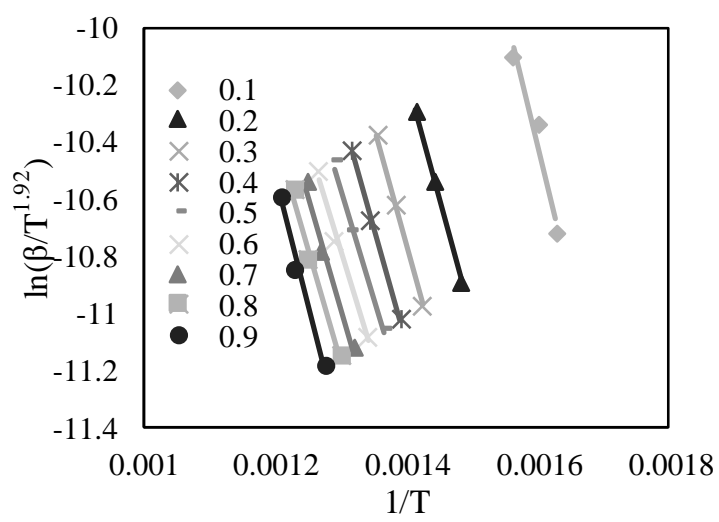

Fig. 8. The plot of $\ln \left(\beta / \mathrm{T}^{1.92}\right)$ against $1 / \mathrm{T}$ for different heating rates at a constant $\alpha=0.1$ to $\alpha=0.9$ in $\mathrm{Ag} / \mathrm{TiO}_{2}$.

\section{Conclusion}

The oxidation activity of silver catalyst supported on alumina $\left(\mathrm{Al}_{2} \mathrm{O}_{3}\right)$, titanium oxide $\left(\mathrm{TiO}_{2}\right)$, and zirconium oxide $\left(\mathrm{ZrO}_{2}\right)$ were tested by the thermogravimetric analysis (TG) to compare soot oxidation performance. The result silver catalyst support by alumina, titanium, and zirconium. It was success to promoted the soot oxidation because the temperature of soot oxidation reaction, maximum of oxidation rate and activation

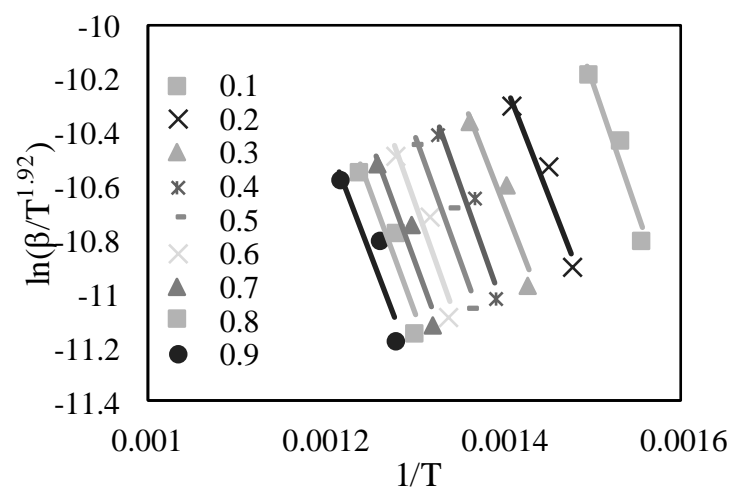

Fig. 9. The plot of $\ln \left(\beta / \mathrm{T}^{1.92}\right)$ against $1 / \mathrm{T}$ for different heating rates at a constant $\alpha=0.1$ to $\alpha=0.9$ in $\mathrm{Ag} / \mathrm{ZrO}$.

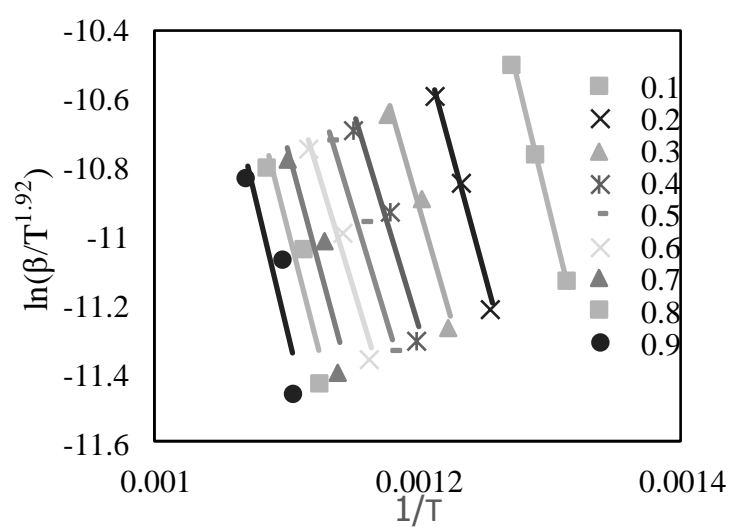

Fig. 10. The plot of $\ln \left(\beta / \mathrm{T}^{1.92}\right)$ against $1 / \mathrm{T}$ for different heating rates at a constant $\alpha=0.1$ to $\alpha=0.9$ in pure soot.

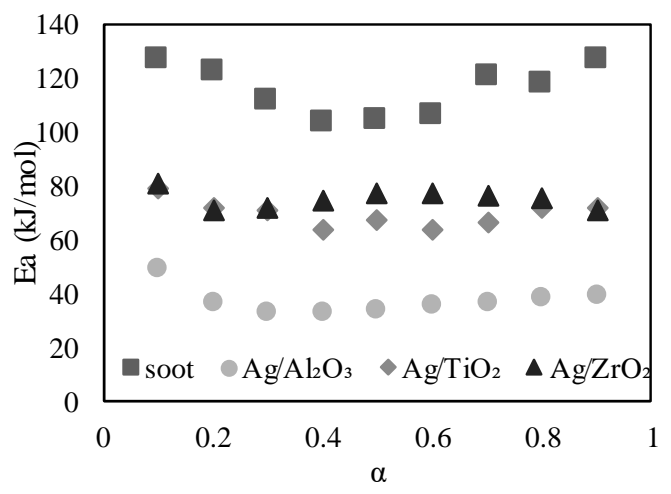

Fig. 11. the comparison of the activation energy from soot oxidation

energy were decrease from temperature in normal soot oxidation. However, the different support in metal oxide group showed the different soot oxidation activity because the activation energy was different which make to different soot oxidation. $\mathrm{Ag} / \mathrm{Al}_{2} \mathrm{O}_{3}$ presented $\mathrm{Ea}=33$ $49 \mathrm{~kJ} / \mathrm{mol}$, it showed good assister for soot oxidation. $\mathrm{Ag} / \mathrm{TiO} 2$ presented $\mathrm{Ea}=64-79 \mathrm{~kJ} / \mathrm{mol}$ and $\mathrm{Ag} / \mathrm{ZrO}_{2}$ presented $\mathrm{Ea}=71-81 \mathrm{~kJ} / \mathrm{mol}$ that the rank of activation energy were similar values, it showed similar of the soot oxidation performance. In future work, the researchers will study the structural characterizations in several catalysts supported by the oxide metal such as specific surface area, crystal structure, and electric state of surface area, etc because some the characteristics of surface properties may assist to promote soot. 


\section{Acknowledgement}

This research was supported the budget grant from KMUTNB-NSTDA High Performance Post Graduate Scholarship in Science and Technology (KMUTNBNSTDA HiP Scholarship) and King Mongkut's University of Technology North Bangkok. The researcher would like to show my appreciation in being supported for this research project until it was accomplished very well.

\section{References}

1. S. Li et al., Oxidative reactivity enhancement for soot combustion catalysts by co-doping silver and manganese in ceria, Applied Catalysis A: General., 570, (2019):299-307,

2. S. N. K. Reddy and M. M. Wani, A comprehensive review on effects of nanoparticles-antioxidant additives-biodiesel blends on performance and emissions of diesel engine, Applied Catalysis A: General., 13, 4(2020): 285-298

3. B. Sawatmongkhon et al., Catalytic oxidation of diesel particulate matter by using silver and ceria supported on alumina as the oxidation catalyst, Appl. Applied Catalysis A: General., 574 , (2020): 33-40

4. K. Krishna, A. Bueno-López, M. Makkee, and J. A. Moulijn, Potential rare earth modified $\mathrm{CeO} 2$ catalysts for soot oxidation. I. Characterisation and catalytic activity with $\mathrm{O} 2$, Applied Catalysis B: Environmental., 75, 3-4(2007):189-200, 2007,

5. J. Zokoe and P. J. McGinn, Catalytic diesel soot oxidation by hydrothermally stable glass catalysts, Chemical Engineering Journal, 262, (2015): 68-77,

6. R. Matarrese, L. Castoldi, and L. Lietti, Oxidation of model soot by $\mathrm{NO} 2$ and $\mathrm{O} 2$ in the presence of water vapor, Chemical Engineering Science., 173, 2(2017): 560-569

7. A. Bueno-López, Diesel soot combustion ceria catalysts, Applied Catalysis B: Environmental., 146, (2014): 1-11

8. T. S. Nguyen, F. Morfin, M. Aouine, F. Bosselet, J. L. Rousset, and L. Piccolo, Trends in the CO oxidation and PROX performances of the platinumgroup metals supported on ceria, Catalysis Today, 253, (2015): 106-114

9. M. S. Chen, Y. Cai, Z. Yan, K. K. Gath, S. Axnanda, and D. W. Goodman, Highly active surfaces for $\mathrm{CO}$ oxidation on $\mathrm{Rh}, \mathrm{Pd}$, and $\mathrm{Pt}$, Surface Science., 601, 23(2007): 5326-5331

10. K. ichi Shimizu, H. Kawachi, and A. Satsuma,
Study of active sites and mechanism for soot oxidation by silver-loaded ceria catalyst, Applied Catalysis B: Environmental., 96, 1-2(2010): 169175

11. L. Nossova, G. Caravaggio, M. Couillard, and S. Ntais, Effect of preparation method on the performance of silver-zirconia catalysts for soot oxidation in diesel engine exhaust, Applied Catalysis B: Environmental., 225, (2018): 538-549

12. E. Aneggi, J. Llorca, C. de Leitenburg, G. Dolcetti, and A. Trovarelli,Soot combustion over silversupported catalysts, Applied Catalysis B: Environmental., 91, 1-2( 2009): 489-498

13. L. Zeng, L. Cui, C. Wang, W. Guo, and C. Gong, Ag-assisted $\mathrm{CeO} 2$ catalyst for soot oxidation, Frontiers of Materials Science., 13, 3(2019): 288295

14. M. Machida, Y. Murata, K. Kishikawa, D. Zhang, and $\mathrm{K}$. Ikeue, On the reasons for high activity of $\mathrm{CeO} 2$ catalyst for soot oxidation, Chemistry of Materials., 20, 13(2008): 4489-4494

15. C. M. Álvarez-Docio, R. Portela, J. J. Reinosa, F. Rubio-Marcos, and J. F. Fernández,Pt mechanical dispersion on non-porous alumina for soot oxidation, Catal. Commun., 140, (2020) : 105999

16. M. J. Kim et al., $\mathrm{CeO} 2$ promoted $\mathrm{Ag} / \mathrm{TiO} 2$ catalyst for soot oxidation with improved active oxygen generation and delivery abilities, J. Hazard. Mater., 384, (2020): 121341

17. H. Shimokawa, Y. Kurihara, H. Kusaba, H. Einaga, and Y. Teraoka, Comparison of catalytic performance of Ag- and K-based catalysts for diesel soot combustion, Catalysis Today, 185, 1(2012): 99-103

18. N. Zouaoui, M. Issa, D. Kehrli, and M. Jeguirim, $\mathrm{CeO} 2$ catalytic activity for soot oxidation under NO / O 2 in loose and tight contact, Catalysis Today, 189, 1(2012): 65-69

19. R. López-Fonseca, I. Landa, U. Elizundia, M. A. Gutiérrez-Ortiz, and J. R. González-Velasco,A kinetic study of the combustion of porous synthetic soot, Chemical Engineering Journal., 129, 13(2007): 41-49

20. S. Vyazovkin, A. K. Burnham, J. M. Criado, L. A. Pérez-maqueda, C. Popescu, and N. Sbirrazzuoli, Thermochimica Acta ICTAC Kinetics Committee recommendations for performing kinetic computations on thermal analysis data, Thermochimica Acta, 520, 1-2(2011): 1-19 